\title{
Towards Ecologically Relevant Targets: Impact of flow and sediment discharge on seagrass communities in the Great Barrier Reef
}

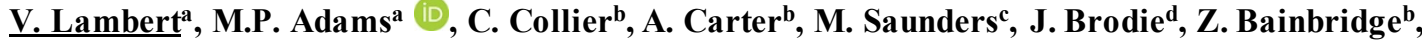 \\ M. Rasheed ${ }^{\mathrm{b}}$, R. Turner ${ }^{\mathrm{e}}$ and K.R. O'Brien ${ }^{\mathrm{a}}$ \\ ${ }^{a}$ School of Chemical Engineering, The University of Queensland, Brisbane QLD Australia, ${ }^{b}$ TropWATER, \\ James Cook University, Townsville QLD Australia, ${ }^{c}$ Tropical Coastal Team, CSIRO Oceans and \\ Atmosphere, Brisbane QLD Australia, ${ }^{d}$ ARC Centre of Excellence for Coral Reef Studies, James Cook \\ University, Townsville QLD Australia, ${ }^{e}$ Water Quality \& Investigations, Department of Environment and \\ Science, Dutton Park QLD Australia, \\ Email: v.lambert@uq.edu.au
}

\begin{abstract}
Catchment degradation causing increased sediment flow is one of the key stressors facing Great Barrier Reef (GBR) habitats. Ecologically relevant targets (ERTs) for sediment and nutrient loads have been previously proposed based on seagrass light requirements, the next step is to connect these to ecological response. The overarching goal of the present work is to recommend preliminary thresholds that can be used in the development of more refined ERTs. To achieve this, we perform statistical analysis on datasets for catchment flows and sediment loads and condition of the adjacent sea gra ss habitat, to identify what might be the direct impacts of catchment discharge on sea grass and the associated timescales of ecological response.

Our case study focuses on Cleveland Bay, which is located in the central GBR, and has important seagrass habitat that is affected by discharge from the Burdekin River. Annual monitoring of sea gra ss bioma ss and area has been undertaken since 2007. We compa re these ecological time-series with data for Burdekin River annual flow and totalsediment load from 2005 onwards.

Annual Burdekin River flow varied by nearly 40-fold within the 2005-2018 study period, and declines in biomass and area of both subtidaland intertidal sea gra sses were associa ted with high flows and loads from the Burdekin. Subtidal seagrasses appeared more sensitive to changes in catchment discharges than intertidal seagrasses, exhibiting a 3 yeartimeframe for recovery, following high annual flows and loads.

Based on our results, a linear model relating change in seagrass biomass to Burdekin River metrics was used to calculate predicted thresholds below which seagrass biomass was likely to increase, and above which biomass was likely to decline. For sea grass a rea, a growth threshold, below which sea grass a rea expanded; and a decline threshold, above which sea gra ss a rea fell, were defined for annualBurdekin River flow, and sediment load. Overall these thresholds provide the first steps towards refining ERTs based on ecological condition, which can directly inform the management of the GBR to protect its iconic seagrass habitats and associated communities. The next step is to examine whether the relationship between river discharge and sediment load was the primary cause of sea grass decline.
\end{abstract}

Keywords: Seagrass, sediment, ecologically relevant target, catchment loads 
Lambert et al., Towards Ecologically Relevant Targets: Impact of flow and sediment discharge on sea grass communities in the Great Barrier Reef

\section{INTRODUCTION}

Catchment runoff presents a major threat to water quality and ecosystem health within the Great Barrier Reef (GBR) (Grech et al. 2011, Bainbridge et al. 2018). Ecologically Relevant Targets (ERTs) for sediment and nutrient loads and pesticide concentrations have been proposed based on seagrass light requirements (Brodie et al. 2017a,b) and incorporated into the 5-year Reef 2050 Water Quality Improvement Plan (The State of Queensland,2018). This paper extends the work of Brodie et al. (2017a,b), by exma ining how catchment loads related to observed changes in seagrass area and biomass.

Seagrass is a key ecosystem of the GBR (Coles et al. 2015) that provides habitat and food formarine a nimals, including iconic megafauna such as turtles and dugongs, along with a range of other ecosystem services. Criteria for seagrass persistence are typically represented as a minimum average annual benthic light requirement (Erftemeijer and Lewis 2006); however in practice, light requirements vary between species, and a lso depend on the duration of light deprivation (Collier et al.2016). For example, a short-duration (4-12 weeks of low light) light threshold of $6 \mathrm{~mol}$ photons $\mathrm{m}^{-2} \mathrm{~d}^{-1}$ has been proposed for the common species Zostera muelleri (Chartrand et al. 2016). Small, colonising species decline rapidly under light deprivation, but large, persistent species survive up to 2 years, even under extreme light deprivation (O'Brien et al. 2018). The timescales of seagrass response to changes in benthic light availability have also been quantified (e.g. Adams et al. 2015). However, neither the sensitivity to or timescale of sea gra ss response to changes in catchment runoff from adjacent land (Saunders et a 1.2017), which potentially regula tes the benthic light a vailability for sea grass, have been quantified in the GBR from mea sured data. This is needed so that ERTs over appropriate scales can be developed.

This study investigates how seagrass condition is related to catchment runoff and associated sediment loads, in a step towards defining ecologically relevant targets for catchment remediation. We chose Cleveland Bay within the GBR for our study, as it possesses an ecologically important and well-studied sea grass habitat.

\section{METHOD}

Annual surveys of seagra ss biomass and extent from Cleveland Bay were compared with discharge and sediment loads from the Burdekin River to investigate the relationship between riverine discharge and seagrass state. The study period (2005-2018) captured several large discharge events from 2007-2012 including flooding caused by a monsoonal low (2008), tropical cyclones Charlotte and Ellie (2009), Tasha (2010/2011) and Yasi (2011). Low flows were recorded in otheryears.

\subsection{Study site}

The Burdekin River, located over $80 \mathrm{~km}$ south-east of Cleveland Bay, has one of the largest catchments in Australia $\left(133,432 \mathrm{~km}^{2}\right.$, see Figure 1), and has a large influence on the GBR. It has extremely variable flow, with high flow and discharge of sediment and nutrients following high rainfall, often associated with tropical cyclones.

\subsection{Cleveland Bay seagrass}

In Cleveland Bay, turbidity and hence the light climate is governed by resuspension of fine sediment flocs in periods of high wind. The flocs are delivered to the Bay in Burdekin River discharge flood plumes as shown clearly in satellite images (Figure 1 inset, Ba inbridge et al. 2012; Fabricius et al.2014; Schroeder et al. 2012). Records of turbidity from the Bay show the relationship between turbidity (and benthic light) and wind speed and direction (McDonald et al. 2013). Seagrass surveys have been conducted annually during peak growing season (September to December) since 2007 as part of the Port of Townsville monitoring program, assessing above-ground biomass and species composition (Bryant et al 2018). There are many potential indicators for seagrass condition (McMahon et al. 2013): here we used biomass as a

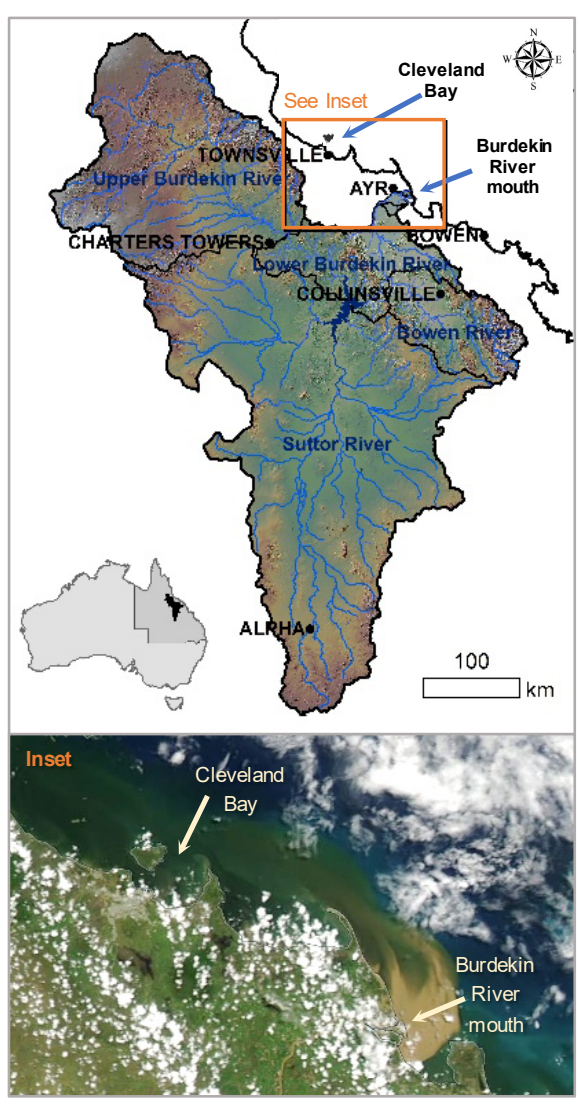

Figure 1. Burdekin River catchment. Inset: Sediment from the Burdekin River flood plume dispersing towards Cleveland Bay (NASA Worldview 9 February 2019). White a reas are clouds. 
Lambert et al., Towards Ecologically Relevant Targets: Impact of flow and sediment discharge on sea grass communities in the Great Barrier Reef

measure of density of the plants, and area to describe spatial extent. This follows on from the work of Collier and others (submitted), who categorised Cleveland Bay seagrasses into two subtidal (deep and shallow) and five intertidal seagrass community types, depending on species composition, depth/intertidal exposure, sediment type and water quality. They quantified mean biomass and spatial extent for each community type, with the exception of the deep subtidal community where area estimates are not available as it is not sampled as frequently (Collier et al. submitted).

For our analysis, seagrass area for all five intertidal community types was added together to obtain a total intertidal area for each year, and sea grass a rea across the shallow subtidal community was added together to obta in a total shallow subtidal area for each year. Total sea gra ss a rea for ea ch year was equal to shallow subtidal and intertidal area combined. Similarly, we estimated mean biomass for the total intertidal, shallow subtidal and deep subtidal seagrasses by first averaging the mean biomass values across each community type. Subsequently for intertidal seagrasses we averaged the five mean biomass values associated with the five intertidal community types, for each year. The mean biomass across all seagrass communities for each year was a lso ca lculated by a vera ging the mean biomass for ea ch sea gra ss community. Hence our data for sea gra sses consisted of time series for seven different types of seagrass condition: intertidal area, shallow subtidal area, total sea gra ss a rea, mean intertidalbiomass, mean shallow subtidal biomass, mean deep subtidalbiomass, and mean sea gra ss biomass.

\subsection{Burdekin River discharges and suspended sediment data}

Burdekin River annual flow (2002 to 2018) and total sediment load data (1949 to 2018) were sourced from collated data from many published sources (Stephen Lewis, pers. comm.). Historical river flow data also came from various sources, including the Bureau of Meteorology (1922-1957 Home Hill gauging station 120001A data), Reef CRC (1966-1995 data from King, 2002) as well as Source Catchment Model predictions (19962001). Data was summarized annually using a "water year" from October to September. Whilst it is acknowledged that the light climate (i.e. water clarity) in Cleveland Bay is also influenced by riverine nutrient loads (Bainbridge et al. 2018, Fabricius et al. 2014), this preliminary study focuses only on river discharge and sediment loads as predictor variables.

\subsection{Modelling approach}

For each year of seagrass monitoring data, the seven metrics of seagrass condition (see Section 2.2) were compared aga inst Burdekin River metrics (annual flow, total suspended sediment load; see Section 2.3) for both the preceding water year and multiple years (by summing the preceding three years of flow or load) to assess temporally-cumulative impacts. To account for prior state of seagrass, annualchange in area and biomass were also compared against annual flow and sediment load for the preceding year. Separate linear models for each pair of predictor(Burdekin River) and response (Cleveland Bay sea grass) va riables were fitted using the $\mathrm{R}$ function $\mathrm{lm}$ (stats package). Correlation coefficients $\left(\mathrm{R}^{2}\right)$ and $\mathrm{p}$-values associated with these models were computed to investigate the strength of the relationships.

The linear model relating change in sea gra ss biomass to Burdekin River metrics was used to calculate predicted thresholds below which seagrass biomass was more likely to expand and above which it was more likely to decline. For seagrass area, two thresholds were observed for each Burdekin River metric: a growth threshold, below which seagrass area expanded; and a decline threshold, above which sea gra ss area fell.

\section{RESULTS AND DISCUSSION}

\subsection{Flow, sediment and seagrass variation over time is high}

Annual Burdekin River flow varied by nearly 40-fold within the 2005-2018 study period, with a minimum observed value of $881 \mathrm{GL}$ in 2015 and a maximum observed value of 34,834 GL in 2011 (Figure 2). Sediment loads generally increased with flow; however, the highest annualload (2008) did not correspond to the highest annualflow (2011), which has been attributed to the influence of drought-breaking flood years (i.e. 2008) and the a vailability of sediment supply across this large catchment (Bainbridge et al. 2014).

Annual seagrass sampling commenced in 2007 just prior to several years of high flows (2008-2012); during this wet period, both seagrass biomass and area substantially declined. Seagrass biomass fell sharply during the periods of high flows and recovered slowly after 2011 (Figure 2a), while seagrass area declined gradually during the periods of high flows then rebounded rapidly in 2012 (Figure 2b). 
Lambert et al., Towards Ecologically Relevant Targets: Impact of flow and sediment discharge on seagrass communities in the Great Barrier Reef

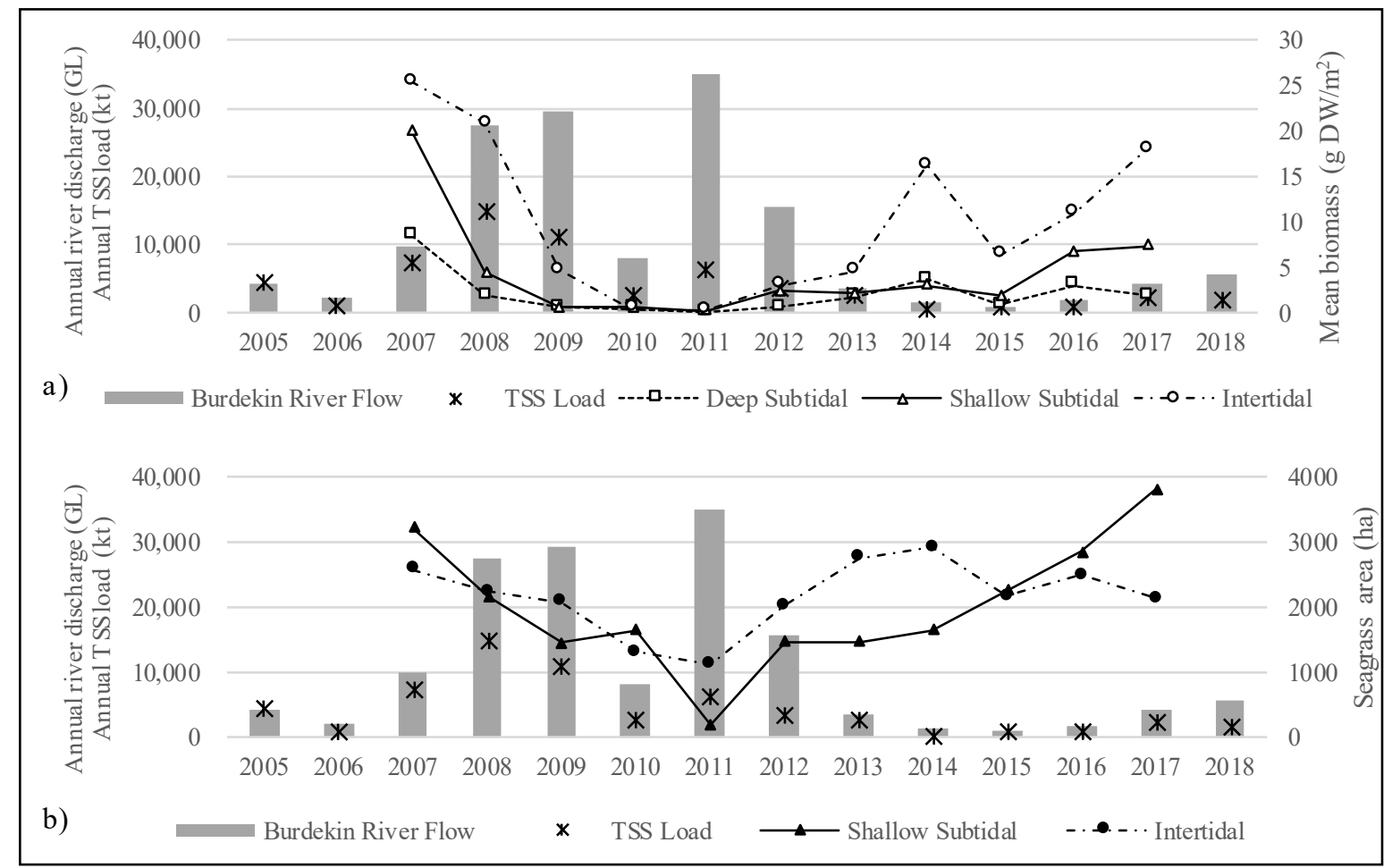

Figure 2. Time series showing variation in a) sea gra ss biomass, and b) sea gra ss a rea in Cleveland Bay with measured annualBurdekin River discharge and annual TotalSuspended Sediment (TSS) load.

\subsection{Cleveland Bay seagrass health is correlated to Burdekin River discharges}

All metrics of Burdekin River discharge were either negatively correlated or not correlated with Cleveland Bay seagrass condition. The strength of all tested correlations are shown in Table 1. Sensitivity to inflows from the Burdekin River was lower in the communities that are exposed to high light during low tide (i.e. intertidal communities), compared to the subtidal sea grass which could be more strongly impacted by light attenuation. For example, the number of statistically significant relationships between shallow subtidal area/biomass and various river discharge metrics (5 out of 16) was higher than the equivalent for intertidal sea grass (2 out of 16). Since subtidal sea grass appeared to be more sensitive to river discharge than intertidal seagrass, and data for deep subtidal seagrass area was not available, the remainder of this paper focuses on observed relationships between the sensitive shallow subtidal community and different discharge metrics.

Table 1. Results of linear models $\left(\mathrm{R}^{2}\right)$ for different predictor (Burdekin River) and response (Cleveland Bay sea grass) variables. Significance indicated by $* \mathrm{p}<0.05 ; * * \mathrm{p}<0.01 ; * * * \mathrm{p}<0.001$.

\begin{tabular}{|c|c|c|c|c|c|c|}
\hline \multicolumn{3}{|c|}{ Cleveland Bay Seagrass } & \multicolumn{4}{|c|}{ Burdekin River Predictor Variables } \\
\hline Community & Metric & $\begin{array}{l}\text { Response } \\
\text { Variable }\end{array}$ & \multicolumn{2}{|c|}{ Flow } & \multicolumn{2}{|c|}{ TSS Load } \\
\hline Deep Subtidal & Biomass & Average & 0.10 & 0.28 & 0.00 & 0.10 \\
\hline \multirow[t]{3}{*}{ Shallow Subtidal } & \multirow[t]{2}{*}{ Area } & Total & 0.30 & $0.66 * *$ & 0.02 & 0.25 \\
\hline & & Annual Change & $0.59 * *$ & 0.27 & $0.50 *$ & $0.40 *$ \\
\hline & Biomass & Average & 0.06 & 0.29 & 0.02 & 0.09 \\
\hline \multirow[t]{4}{*}{ Intertidal } & \multirow[t]{2}{*}{ Area } & Total & 0.30 & 0.34 & 0.02 & 0.27 \\
\hline & & Annual Change & 0.01 & 0.02 & 0.03 & 0.07 \\
\hline & \multirow[t]{2}{*}{ Biomass } & Average & 0.04 & $0.44 *$ & 0.07 & 0.11 \\
\hline & & Annual Change & 0.22 & 0.14 & 0.30 & $0.42 *$ \\
\hline \multirow[t]{2}{*}{ All Seagrass Communities } & \multirow[t]{2}{*}{ Area } & Total & $0.41 *$ & $0.72 * *$ & 0.03 & 0.35 \\
\hline & & Annual Change & 0.39 & 0.11 & 0.38 & 0.37 \\
\hline
\end{tabular}


Lambert et al., Towards Ecologically Relevant Targets: Impact of flow and sediment discharge on seagrass communities in the Great Barrier Reef

\subsection{Seagrass area declines with cumulative flow}

Although annual flow from the Burdekin River was not correlated with shallow subtidal seagrass area, cumulative flow (3 yr summed values) was (Table 1). As the sum of the annual flow from the previous 3 years increased, seagrass area in Cleveland Bay declined (Figure 3). This timeframe corresponds to the successive years of above-average rainfall and discharge (Bainbridge et al. 2012) that were associated with the decline, and suggests that 3 years is the approximate timeframe for recovery. This recovery period may include both benthic light recovery, followed by sea grass recovery: Fabricius et al. (2014) suggest recovery of photic depth following a big discharge event takes around 1.5 years, with continued low photic depth following

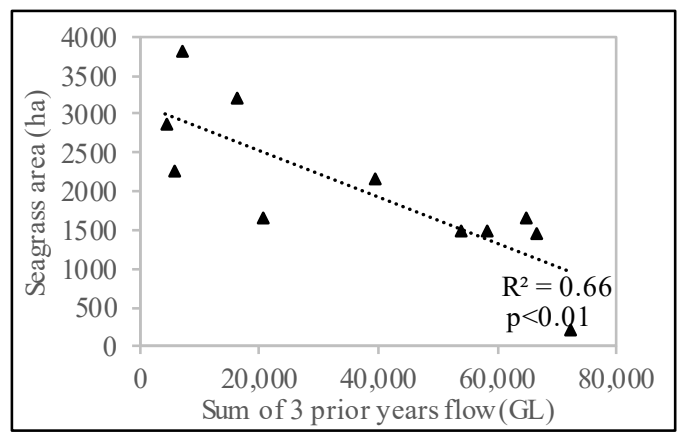

Figure 3. Impact of cumula tive Burdekin River flow (sum of previous 3 years) on shallow subtidal sea grass a rea in Cleveland Bay. sequentialhigh flows.

\subsection{Annual change in seagrass area and biomass is negatively correlated to sediment load}

Annual sediment load from the Burdekin River did not correlate with seagrass biomass or area in Cleveland Bay for any of the seagrass community types (Table 1). The poor correlation may be affected by data from recovering communities that have low biomass and area but are on an improving trajectory. In contrast, annual change in seagrass biomass and area correlated well with annual TSS loads, with biomass more strongly correlated than area (Table 1, Figure 4). For each Burdekin River metric in Figure 4a, the predicted threshold represents the flow or load below which seagrass is more likely to grow, and above which seagrass is more likely to decline.

For sea gra ss a rea, each da ta point in Figure $4 \mathrm{~b}$ (representing an individual year) fell into one of two categories: (1) seagrass area increased, and flows or loads were below a certain value which we called the growth threshold, or (2) sea grass a rea declined, and flows or loads exceeded a certain value which we called the decline threshold (Table 2).

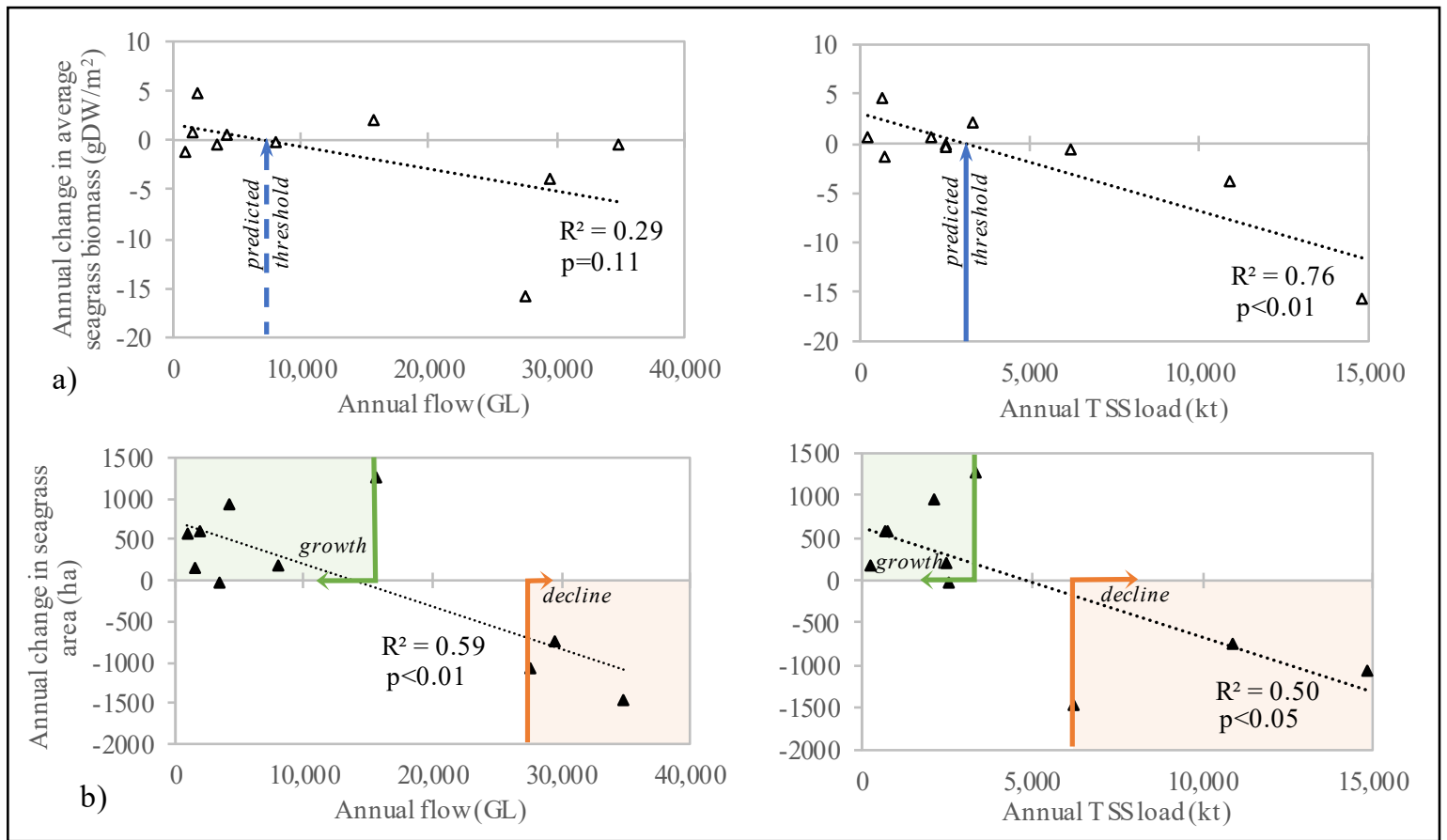

Figure 4. The effect of annual flow and sediment load from the Burdekin River at Home Hill on annual change in Cleveland Bay shallow subtidal sea grass: a) mean biomass; and b) a rea. Indicated thresholds include a) predicted thresholds (blue arrow) based on the model intercept when change in biomass (y-axis) is zero; and b) observed thresholds for i) growth (green), below which area was observed to increase, and ii) decline (orange), above which seagrass a rea was observed to decline. 
Lambert et al., Towards Ecologically Relevant Targets: Impact of flow and sediment discharge on sea grass communities in the Great Barrier Reef

For seagrass biomass, thresholds distinguishing between seagrass growth and decline could not be as clearly defined as for area. Rather, a predicted threshold in flow or load, above which seagrass is more likely to decline and below which seagrass is more likely to grow, could be estimated from the $x$-intercept of the linear relationship between biomass and flow or load (Table 2 and Figure $4 \mathrm{a}$ ).

All three threshold types (predicted, growth and decline) shown in Table 2 could be used to derive potential ERTs (with the exception of biomass-flow as this correlation was not significant at $\mathrm{p}=0.05$ level). Since predicted thresholds (based on biomass) are lower than the observed thresholds derived from seagrass area, ERTs based on the predicted thresholds are more conservative. Predicted thresholds are also advantageous because they possess similar values to the median value of flows and loads seen from historic data (Table 2). On the otherhand, ERTs based on the areaderived growth and decline thresholds are easier to interpret but are separated by a region of uncertainty.

For development of potential ERTs, we caution that the relatively short study period (2005-2018) conta ins three of the six largest discharge years on record. Extending the analysis to include sea grass monitoring results for the most recent wet years (2017-2018, 2018-2019), once available, may add greater resolution to the analysis. It is also possible that other factors associated with large Burdekin River discharges also affect seagrass in Cleveland Bay, e.g. nutrients or other contaminants, sediment size distribution or resuspension. Distinguishing impacts from the Burdekin River and smaller local rivers also requires further study.

\section{CONCLUSIONS AND RECOMMENDATIONS}

Sea gra ss biomass and area in Cleveland Bay declined with increased multi-year flows and sediment load from the Burdekin River. Sea gra ss area and a nnual change in a rea correlated with river flow for the shallow subtidal communities, while annual change in sea grass biomass was more strongly rela ted to sediment load. There were also differences in the strength of correlations depending on the community: the subtidal communities were more highly correlated with flow and sediment loads than intertidal communities, and may therefore be appropriate sentinel communities a gainst which to set ERTs. Future work could investigate whether the five intertidal communities (Collier et al. submitted) are also more sensitive to sediment loads, than the intertidal community as a whole.

Future research is needed to investiga te the effect of the sediment load that reaches Cleveland Bay, rather than the entire load coming from the Burdekin River, especially since the former will include a larger proportion of fine sediments preferentially transported in flood plumes. The time-lags for seagrass to react to and recover from large flows and sediment loads, that we observed, are longer than those observed in previous short-term experimental studies. Confirming the cause-effect pathway linking sediment loads to seagrass changes also requires examination of changes in light levels, which are expected to be the intermediate link between catchment load changes and their impacts on sea gra ss condition.

\section{ACKNOWLEDGEMENTS}

This project is funded through the Australian Government's National Environmental Science Programme (NESP) Tropical Water Quality Hub and the Great Barrier Reef Foundation. The authors would like to thank Gra eme Curwen for development of maps for Figure 1, Robin Ellis for input and Stephen Lewis (TropWATER, James Cook University) for providing suspended sediment data. We also thank the Port of Townsville Limited for their support and funding of the long-term sea grass monitoring program for Cleveland Bay.

\section{REFERENCES}

Adams, M. P., A. J. P. Ferguson, C. J. Collier, M. E. Baird, R. K. Gruber, and K. R. O’Brien. 2015. Assessment of light history indicators for predicting seagrass biomass. 21 st International Congress on Modelling and Simulation, Gold Coast, Austra lia, 1303-1309.

Bainbridge, Z.T., Wolanski, E., Álvarez-Romero, J.G., Lewis, S.E., Brodie, J.E. 2012. Fine sediment and nutrient dynamics related to particle size and floc formation in a Burdekin River flood plume, Australia. Marine Pollution Bulletin, 65 (4-9), 236-248. 
Lambert et al., Towards Ecologically Relevant Targets: Impact of flow and sediment discharge on sea grass communities in the Great Barrier Reef

Bainbridge, Z.T., S. Lewis, R. Bartley, K. Fabricius, C. Collier, J. Waterhouse, A. Garzon-Garcia, B. Robson, J. Burton, A. Wenger, and J. Brodie. 2018. Fine sediment and particulate organic matter: a review and case study on ridge-to-reef transport, transformations, fates and impacts on marine ecosystems. Marine Pollution Bulletin 135.

Ba inbridge Z, Lewis S, Smithers S, Kuhnert P, Henderson B and Brodie J. 2014. Fine-suspended sediment and water budgets for a large, seasonally dry tropical catchment: Burdekin River catchment, Queensland, Australia. Water Resources Research, 50 (11).

Brodie, J., Baird, M., Waterhouse,J., Mongin, M., Skerratt, J., Robillot, C., Smith, R., Mann, R., Warne, M., 2017a. Development of ba sin-specific ecologically relevant water qua lity targets for the Great Barrier Reef. TropWATER Report No. 17/38, James Cook University, Published by the State of Queensland, Brisbane, Australia. $68 \mathrm{pp}$.

Brodie, J., Baird, M., Mongin, M., Skerratt, J., Robillot C., Waterhouse J. 2017. Pollutant target setting for the Great Barrier Reef: Using the eReefs framework. In: Proceedings of 22nd International Congress on Modelling and Simulation, Hobart, Tasmania, Australia, 3 to 8 December 2017. https://www.mssanz.org.au/modsim2017/

Bryant,C. V., and M. A. Rasheed.2018. Port of Townsville AnnualSeagrass Monitoring Survey: September 2017. James Cook University Publication, Centre for Tropical Water \& Aquatic Ecosystem Research (TropWATER), Cairns.

Chartrand, K. M., C. V. Bryant, A. B. Carter, P. J. Ralph, and M. A. Rasheed.2016. Light thresholds to prevent dredging impacts on the Great Barrier Reef seagrass, Zostera muelleri ssp. capricorni. Frontiers in Marine Science 3:106.

Coles, R. G., M. A. Rasheed, L. J. McKenzie, A. Grech, P. H. York, M. Sheaves, S. McKenna, and C. Bryant. 2015. The Great Barrier Reef World Heritage Area seagrasses: Managing this iconic Australian ecosystem resource for the future. Estuarine, Coastal and Shelf Science 153: A1-A12.

Collier, C. J., M. P. Adams, L. Langlois, M. Waycott, K. R. O'Brien, P. S. Maxwell, and L. McKenzie. 2016. Thresholds for morphological response to light reduction for four tropical seagrass species. Ecological Indica tors 67:358-366.

Collier, C.J., A. Carter, M. Rasheed, L. McKenzie, J. Udy, R. Coles, J. Brodie, M. Waycott, K. O'Brien, M.P. Adams, K. Martin, C. Honchin, C. Petus, E. Lawrence. Submitted. Determining 'desired state' targets for a daptive management of dynamic and diverse sea grass habitats.

Erftemeijer, P. L. A. and R. R. R. Lewis III. 2006. Environmentalimpacts of dredging on seagra sses: A review. Marine Pollution Bulletin 52: 1553-1572.

Fabricius, K.E., Logan, M., Weeks, S., Brodie, J.2014. The effects of river run-off on water clarity across the central Great Barrier Reef. Marine Pollution Bulletin, 84 (1-2), 191-200.

Grech, A., R. Coles, and H. Marsh. 2011. A broad-scale assessment of the risk to coastal seagrasses from cumulative threats. Marine Policy 35:560-567.

King, B., McAllister, F. and Done, T. 2002. Modelling the impact of the Burdekin, Herbert, Tully and Johnstone River plumes on the Central Great Barrier Reef. CRC Reef Research Centre Technical Report No 44, CRC Reef Research Centre, Townsville.

Macdonald, R.K., Ridd, P.V., Whinney, J.C., Larcombe, P. and Neil, D.T., 2013. Towards environmental management of water turbidity within open coastal waters of the Great Barrier Reef. Marine Pollution Bulletin, 74(1), 82-94.

McMahon, K., C. Collier, and P. S. Lavery.2013. Identifying robust bioindicators of light stress in seagra sses: a meta-analysis. Ecological Indicators 30:7-15.

O'Brien, K. R., M. Waycott, P. Maxwell, G. A. Kendrick, J. W. Udy, A. J. P. Ferguson, K. Kilminster, P. Scanes, L. J. McKenzie, K. McMahon, M. P. Adams, J. Samper-Villarreal, C. Collier, M. Lyons, P. J. Mumby, L. Radke, M. J. A. Christianen, and W. C. Dennison. 2018. Sea gra ss ecosystem trajectory depends on the relative timescales of resistance, recovery and disturbance. Marine Pollution Bulletin 134:166-176.

Saunders, M. I., M. Bode, S. Atkinson, C. J. Klein, A. Metaxas, J. Beher, M. Beger, M. Mills, S. Giakoumi, V. Tulloch, H. P. Possingham. 2017. Simple rules can guide whether land- or ocean-based conservation will best benefit marine ecosystems. PLoS Biology 15: e2001886.

Schroeder, T., Devlin, M.J., Brando, V.E., Dekker, A.G., Brodie, J.E. 2012. Inter-annual variability of wet sea son freshwater plume extent into the Great Barrier Reef lagoon based on satellite coastalocean colour observations. Marine Pollution Bulletin 65:210-223.

The State of Queensland. 2018. Reef 2050 Water Quality Improvement Plan 2017-2022. Reef Water Quality Protection Plan Secretariat, Brisbane. 